\title{
Correction to: Associations of preoperative stroke and tranexamic acid administration with convulsive seizures in valvular open-heart surgery
}

\author{
Nikolai Hulde ${ }^{1} \cdot$ Armin Zittermann $^{2}(1) \cdot$ Marcus-André Deutsch ${ }^{2} \cdot$ Vera von Dossow $^{1} \cdot$ Jan F. Gummert ${ }^{2}$. \\ Andreas Koster ${ }^{1}$
}

Published online: 28 April 2021

(C) The Author(s) 2021

\section{Correction to: Journal of Anesthesia https://doi.org/10.1007/s00540-021-02924-w}

In the original publication of the article, corresponding author's last name was published incorrectly as "Zitttermann". The correct name is "Armin Zittermann".

The original article has been corrected.

Open Access This article is licensed under a Creative Commons Attribution 4.0 International License, which permits use, sharing, adaptation, distribution and reproduction in any medium or format, as long as you give appropriate credit to the original author(s) and the source, provide a link to the Creative Commons licence, and indicate if changes were made. The images or other third party material in this article are included in the article's Creative Commons licence, unless indicated otherwise in a credit line to the material. If material is not included in the article's Creative Commons licence and your intended use is not permitted by statutory regulation or exceeds the permitted use, you will need to obtain permission directly from the copyright holder. To view a copy of this licence, visit http://creativecommons.org/licenses/by/4.0/.

Publisher's Note Springer Nature remains neutral with regard to jurisdictional claims in published maps and institutional affiliations.
The original article can be found online at https://doi.org/10.1007/ s00540-021-02924-w.

Armin Zittermann azittermann@hdz-nrw.de

1 Institute of Anesthesiology and Pain Therapy, Herzund Diabeteszentrum NRW, Ruhr-University Bochum, Bad Oeynhausen, Germany

2 Clinic for Thoracic and Cardiovascular Surgery, Herz- Und Diabeteszentrum NRW, Bad Oeynhausen, Ruhr-University Bochum, Georgstr. 11, 32545 Bad Oeynhausen, Germany 